\title{
Teachers' Perceptions and Practices of Classroom Assessment in Secondary School Science Classes in Bangladesh
}

\author{
Md. Mehadi Rahman \\ Institute of Education and Research, University of Dhaka, Shahbagh, Bangladesh
}

\begin{abstract}
Classroom assessment is an essential part of education. The study investigated teachers' perceptions of classroom assessment and their current classroom assessments practices in secondary science in Bangladesh. Specifically, the study sought to gain an understanding of to what extent teachers use different classroom assessment strategies to understand and to support both teaching and learning processes and how their perception is related with their classroom assessment practice. The study was mainly quantitative with some integration of qualitative approach. Data sources were secondary science teachers and their science classrooms. The study used a questionnaire to establish the teachers' perceptions of classroom assessment in science, a lesson observation protocol, and prelesson and post-lesson observation interview protocols as main sources of data collection. A total of thirty teachers (twenty male and ten female) were chosen randomly from six secondary schools in Dhaka city. The findings suggest that teachers perceive classroom assessment as summative assessment. What teachers said about their classroom assessment practice was not reflected during their teaching. Therefore, the teachers' perceptions of classroom assessment have no significant relation with their classroom assessment practices.
\end{abstract}

Keywords: classroom assessment, teachers' perception, science classes, secondary school, classroom assessment practice

\section{Introduction}

Assessment is an essential part of education. Classroom assessment is an integral component of the teaching and learning process (Black \& Wiliam, 1998a). Assessment informs the teacher about what students think and about how they think. Assessment determines the degree of the progress made by a teacher in respect of making his students understand the topic he teaches. Assessment guides teachers whether he should change the course of his action, way of delivering things and art of teaching. Most teachers' only think that the assessment aims to measure student's performance but they ignore that it also measures a teacher's performance as well. The more a teacher is expert in assessing his students; the more his teaching performance is improved. A teacher needs to know his individual students ability and classroom assessment helps teachers to confirm what students already know and what they need to learn (Susuwele-Banda, 2005).

In general, assessment is divided into formative and summative forms. Formative assessment is usually done in the classroom while the summative assessment is done after the completion of a particular unit of a course or at the end of a course. According to William and Thompson (2008) assessment system in the classroom is one form of formative assessment. The nature of classroom assessment defines what is valued and what students are learning clearly, what is assessed and how it is assessed. Black and Wiliam (1998b) strongly argued that substantial learning gains are possible if teachers use classroom assessment in formative manner. According to the curriculum the classroom assessment must be formative and the purpose of this assessment is to support students' learning and improve the quality of learning (National Secondary Education Curriculum, 2012).
In Bangladesh, school level assessment system can be classified in two broad categories: first one can be mentioned as assessing during classroom teaching-learning activities which can be termed as classroom assessment; and another is consisted of formal test, or examination known as examination oriented assessment. The assessments that are practiced in secondary school classrooms are far from that of formative assessments. Begum and Ahmed (2007) reported that assessment is mainly guided by paper-pencil based tests within the secondary education system of Bangladesh.

Assessments employed within the day-to-day classroom structure (Classroom assessment) have the potential to improve teacher instruction and pupils' learning (Guskey, 2003). Students' achievements depend on teachers' better performance in applying different techniques of assessment Grant (1996) pointed out that student achievement begins by improving teachers' knowledge of sound classroom assessment practices and principles. How teachers perceive classroom assessment is an indicator of how they practice assessment in classroom. The present study is an attempt to know teachers perception about classroom assessment and reflection of their thinking in the actual classroom practice. How their beliefs on science teaching plays to contribute creating effective teaching learning situation in classroom is the important issue of the study. Thus, the present study is a pointer to grasp what is going on in the classroom, and how teachers' beliefs, thinking and perception about classroom assessment relates with their practice in secondary schools.

\section{Rationale of the Study}

In classroom assessment, teacher conducts different types of assessment, identifies student weaknesses and strengths, encourages students to take part in assessment and provides feedback to students. Teachers cannot diagnose student's

Volume 7 Issue 6, June 2018 www.ijsr.net 


\section{International Journal of Science and Research (IJSR) \\ ISSN (Online): 2319-7064}

Index Copernicus Value (2016): 79.57 | Impact Factor (2017): 7.296

needs; group students intelligently, assign meaningful grades, or evaluate the impact of instructional treatments without sound day to day classroom assessment (Stiggins, 1991). Classroom assessment is an important tool in the hands of the teacher through which quality of education could be assured. It is well documented that assessment has a great influence in teaching and learning (Stiggins \& Chappuis, 2005). But teachers are not aware of this and do not know how to use it effectively.

While it is important to know how teachers implement assessment activities in the classroom, it is equally important to understand the perceptions of the teachers who used the assessment strategies. Because, according to Fennema and Romberg (1999), the way teachers perceive assessment may influence the way they teach and assess their students. Stiggins (2010) suggested that teachers need to develop a solid understanding of classroom assessment so that they can develop a balanced approach to assessment for learning and assessment of learning. Many teachers don't have clear conception about classroom assessment. Susuwele-Banda (2005) found that teachers' showed mismatch between perception of classroom assessment and classroom assessment practices. Classroom assessment practices of teachers play a central role in determining the quality of education. Their perception as to the place of their classroom assessment practices in ensuring quality education is weak and fuzzy (Nenty, Adedoyin, Odili \& Major, 2007).

Yao (2015) stated that teacher perceptions and their practices in classroom assessment may not be totally aligned. Despite teachers reported favorable perception of assessment, they seem to be facing a conflict in effective assessment in their classroom (Ndalichako, 2015). Buyukkarci (2014) also found that while the teachers held positive views of formative assessment and feedback, they did not use formative assessments on a regular basis or in an effective way. Similarly, Danielson (2008) observed that although teachers are trained to develop sound and valid assessment measures, their perceptions and beliefs may affect the way they teach and assess their students.

In Bangladesh secondary science teachers assess students in very few ways in the classroom. Most of the teachers are reluctant in assessing students properly and they don't emphasize on students learning through their classroom assessment. They mainly highlight on students' performance in the examination. Teachers are not oriented with effective classroom assessment strategies and for this reason students are focused on result rather than learning. As it is documented that teachers' classroom assessment practice is guided by their perception, so it is necessary to identify the relationship between teachers' perception and practice of classroom assessment in context of Bangladesh.

\subsection{Purpose of the Study}

The purpose of the study is to understand the secondary science teachers' perceptions and practices of assessment that are held during teaching-learning activities in science classrooms.

\subsection{Research Questions}

In order to satisfy the purpose of the study, a set of specific questions were formulated. The study particularly investigated the following three research questions:

a) How do secondary school science teachers perceive classroom assessment?

b) How do the teachers assess their students' science learning in secondary school classrooms?

c) What is the relationship of teachers' perceptions of classroom assessment with their classroom assessment practices?

\section{Methodology}

This is descriptive study and mainly quantitative with some integration of qualitative approach. In this study data is collected in a computable manner through questionnaires and observation checklist. In quantitative data analysis, all the procedures are statistical. The present study also uses the mathematical way to analyze the data. However, the researcher also integrated some qualitative approach for triangulation for completeness purpose that is significant for increasing in-depth understanding of the phenomena under consideration.

The study was conducted in the secondary school situated in Dhaka City of Bangladesh. The study included only general secondary schools. The population of this study was consisted of in-service secondary science teachers who teach students studying Grade VI to Grade VIII in different secondary schools of Bangladesh. A sample of 30 science teachers was selected for conducting the study. The teachers were chosen randomly from six schools which were located in Dhaka city. One science period (classroom) of each teacher was observed followed by a pre and post observation interview with teachers. Total 30 science periods (classroom) were selected using convenience sampling.

Three data collection instruments were used in this study to elicit appropriate data. The instruments were- questionnaire with a Likert type scale, classroom observation protocol and pre $\&$ post lesson observation interview protocol were used to collect data. Descriptive statistics techniques like percentages, mean and inferential statistics like correlation are used to present quantitative data. The qualitative data was analyzed using predetermined themes that addressed the themes of classroom observation. The teachers have been coded as T1, T2, T3......T30 etc.

\section{Results of the study}

Whether teachers' perceptions and practices of classroom assessment relate or did not relate to each other are discussed below in the following segments under two major headingsTeachers idea about classroom assessment and relation between teachers' perceptions and practice of classroom assessment. 


\section{International Journal of Science and Research (IJSR) \\ ISSN (Online): 2319-7064}

Index Copernicus Value (2016): 79.57 | Impact Factor (2017): 7.296

\subsection{Teachers' idea about Classroom Assessment}

Teachers perceive classroom assessment as summative assessment. Teachers claimed that they have idea about science curriculum and they use lesson plan, but teachers don't have clear knowledge about classroom assessment.

It was guessed that teachers' preliminary concept on curriculum is a pointer to grasp the technique and importance of classroom assessment. $93.33 \%$ teachers knew about the science curriculum. But $6.67 \%$ teachers mentioned that they have no idea about science curriculum.

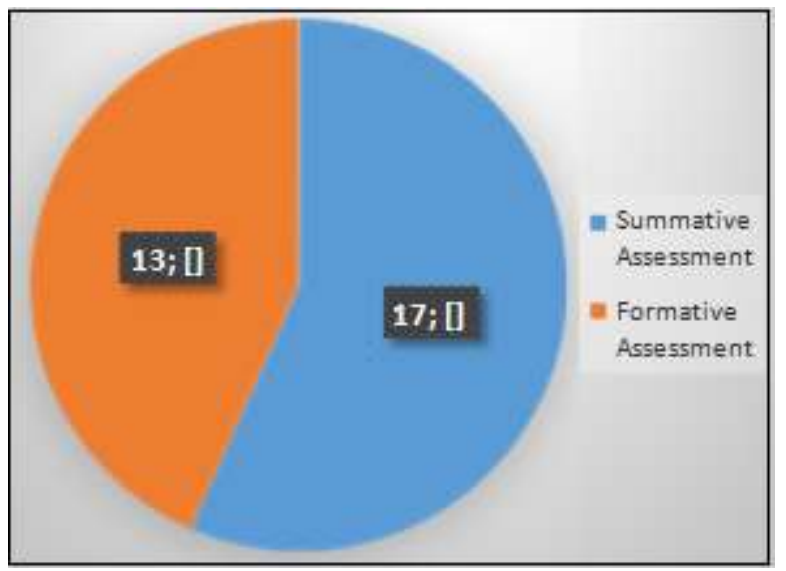

Figure 1: Teachers' conception about classroom assessment

Figure 1 presents that 17 teachers $(56.66 \%)$ selected summative assessment as classroom assessment while 13 teachers $(43.33 \%)$ defined classroom assessment as formative assessment. So, more than half of the teachers concept about classroom assessment is not clear.

Most of the teachers (90\%) thought of classroom assessment to be oral question and answer. A huge percentage of teacher thought of classroom assessment to be planned observation $(83.33 \%)$ and written work $(80 \%)$ as classroom assessment. Majority of the teachers (23 which is $76.67 \%$ of them) mentioned purpose of classroom assessment is to providing guidance to the students learning. $70 \%$ teachers (21) mentioned that their purpose of assessing students is to ensure their participation in teaching learning.

\subsection{Relation between teachers' perceptions and practice of classroom assessment}

\subsubsection{Beginning classroom activities}

Table 1 presents that teachers strongly agreed with both explaining learning objectives $(\mathrm{M}=3.30)$ and discussing topic according to objectives $(\mathrm{M}=3.33)$. Teachers also agreed that students' prior knowledge $(\mathrm{M}=3.13)$ and misconception about science topic $(\mathrm{M}=3.07)$ should be explored. They strongly agreed $(\mathrm{M}=3.37)$ to connect students prior knowledge with new knowledge.
Table 1: Teachers' perception and practice of beginning classroom activities

\begin{tabular}{|c|c|c|c|c|}
\hline Statements & $\mathrm{N}$ & $\begin{array}{c}\text { Perception } \\
\text { Mean }\end{array}$ & $\begin{array}{c}\text { Practice } \\
\text { Mean }\end{array}$ & $\begin{array}{c}\text { Correlation } \\
\text { Coefficient }\end{array}$ \\
\hline $\begin{array}{c}\text { 1. Explaining learning } \\
\text { objectives }\end{array}$ & 30 & 3.30 & 2.67 & $-0.321^{\mathrm{ns}}$ \\
\hline $\begin{array}{c}\text { 2. Discussing topic } \\
\text { according to the learning } \\
\text { objectives }\end{array}$ & 30 & 3.33 & 3.13 & $0.21^{\mathrm{ns}}$ \\
\hline $\begin{array}{c}\text { 3. Exploring students' prior } \\
\text { knowledge }\end{array}$ & 30 & 3.13 & 2.13 & $-0.16^{\mathrm{ns}}$ \\
\hline $\begin{array}{c}\text { 4. Connecting prior } \\
\text { knowledge with new } \\
\text { knowledge }\end{array}$ & 30 & 3.37 & 1.90 & $0.131^{\mathrm{ns}}$ \\
\hline $\begin{array}{c}\text { 5. Exploring students } \\
\text { misconception }\end{array}$ & 30 & 3.07 & 1.43 & $-0.044^{\mathrm{ns}}$ \\
\hline
\end{tabular}

Note. $\mathrm{N}=$ Sample Size, ${ }^{\mathrm{ns}}=$ non-significant

But in practice a major difference is found in beginning classroom activities. Teachers discussed the learning objectives sometimes $(\mathrm{M}=2.67)$ but not all the teacher discussed learning objectives in the class. Some teachers state the topic of the lesson before starting but they do not share any idea of learning objectives with the students. The mean value of 'teachers' discussed the topic according to the learning objectives' $(M=3.13)$ shows that teachers were good at it. Teachers were irregular in exploring students' prior knowledge $(\mathrm{M}=2.13)$. Most of the teacher explored students' prior knowledge through questioning in the classroom. Teachers rarely connected students' prior knowledge with new knowledge $(\mathrm{M}=1.90)$ and/or explored students' misconceptions about science $(M=1.43)$.

The Table 1 shows that teachers' perception about beginning classroom activities has no significant relation with their practice as the $\mathrm{p}$ value is greater than 0.05. Although teachers' perception and practice of statement no. 2 has weak positive correlation and statement no. 1 has weak negative correlation, but all are statistically non-significant.

\subsubsection{Teaching learning activities}

Table 2 presents that teacher strongly agreed to use multiple teaching methods $(\mathrm{M}=3.40)$, engaging students in teaching learning $(\mathrm{M}=3.43)$, providing scope for students to share ideas $(M=3.30)$ and using teaching aids $(M=3.67)$. They also perceive using alternate method if student fails to understand any topic $(\mathrm{M}=3.20)$.

Table 2: Teachers' Perception and Practices about Teaching Learning Activity

\begin{tabular}{|l|c|c|c|c|}
\hline \multicolumn{1}{|c|}{ Statements } & $\mathrm{N}$ & $\begin{array}{c}\text { Perception } \\
\text { Mean }\end{array}$ & $\begin{array}{c}\text { Practice } \\
\text { Mean }\end{array}$ & $\begin{array}{c}\text { Correlation } \\
\text { Coefficient }\end{array}$ \\
\hline $\begin{array}{l}\text { 1. Using multiple } \\
\text { teaching methods }\end{array}$ & 30 & 3.40 & 2.47 & $0.193^{\text {ns }}$ \\
\hline $\begin{array}{l}\text { 2. Engaging students in } \\
\text { teaching learning }\end{array}$ & 30 & 3.43 & 2.77 & $-0.068^{\text {ns }}$ \\
\hline $\begin{array}{l}\text { 3. Providing scope for } \\
\text { students to share ideas }\end{array}$ & 30 & 3.30 & 2.37 & $-0.25^{\text {ns }}$ \\
\hline $\begin{array}{l}\text { 4. Using alternate } \\
\text { method if student fails } \\
\text { to understand }\end{array}$ & 30 & 3.20 & 1.90 & $-0.416^{*}$ \\
\hline 5. Using teaching aids & 30 & 3.67 & 1.40 & $0^{\text {ns }}$ \\
\hline
\end{tabular}

Note. $\mathrm{N}=$ Sample Size, ${ }^{*} \mathrm{p}<0.05,{ }^{\mathrm{ns}}=$ non-significant 


\section{International Journal of Science and Research (IJSR) \\ ISSN (Online): 2319-7064}

Index Copernicus Value (2016): 79.57 | Impact Factor (2017): 7.296

In practice, teachers sometimes used multiple teaching methods $(M=2.47)$ but improvement is required. Most of the teachers used only lecture method in their teaching learning activities. The weighted mean of statement 2 is just 1.90 which indicates most of the teachers didn't used alternative way of teaching if any students fail to understand. Most of the teachers engaged students in teaching learning activities are marginally good $(\mathrm{M}=2.77)$ but it can be improved. Teachers didn't provide well opportunity to share students' idea $(\mathrm{M}=2.37)$ and improvement is required. Most of the teachers didn't encouraged students to talk and share ideas about science in the classroom. Usually, teachers did not permit students to talk or share ideas about any topic discussing in classroom. Similarly, most of the teachers didn't use any teaching aids in the class $(\mathrm{M}=1.40)$.

The Table 2 shows that teachers' perception about different activities of teaching learning has no significant relation with their practices of teaching learning activities in classroom. Teachers' perception of using teaching aids in the class has no linear correlation with their practice but it's statistically non-significant. Teachers strongly agreed to use teaching aids in science classes but in practice very few teachers had practiced it. Teachers' perception about using alternate teaching method if a student's fails to understand the topic has moderate negative $(\mathrm{r}=-.416)$ correlation and $\mathrm{p}$ value is $*_{p}<0.05$. It means the teachers who strongly agreed to use alternate method for students' failure; in practice they are not doing it. In observation it was also found that most of the teachers are using only lecture method.

\subsubsection{Classroom questioning in the classroom}

Table 3 presents that teachers strongly agreed to encourage students to ask questions $(\mathrm{M}=3.40)$. Teachers also expressed their agreement with the idea that both open $(\mathrm{M}=3.23)$ and closed $(\mathrm{M}=2.77)$ question should be asked in science class, questions should be asked whenever necessary $(M=2.65)$ and providing both equal opportunity $(\mathrm{M}=3.03)$ and sufficient time $(\mathrm{M}=2.90)$ to students to answer questions.

Table 3: Teachers' Perception and Practices about classroom questioning in the classroom

\begin{tabular}{|l|c|c|c|c|}
\hline \multicolumn{1}{|c|}{ Statements } & $\mathrm{N}$ & $\begin{array}{c}\text { Perception } \\
\text { Mean }\end{array}$ & $\begin{array}{c}\text { Practice } \\
\text { Mean }\end{array}$ & $\begin{array}{c}\text { Correlation } \\
\text { Coefficient }\end{array}$ \\
\hline $\begin{array}{l}\text { 1. Encouraging students to } \\
\text { ask questions }\end{array}$ & 30 & 3.40 & 2.20 & $-0.292^{\text {ns }}$ \\
\hline $\begin{array}{l}\text { 2. Teacher ask open } \\
\text { questions }\end{array}$ & 30 & 3.23 & 2.23 & $0.082^{\text {ns }}$ \\
\hline $\begin{array}{l}\text { 3. Teacher ask closed } \\
\text { questions }\end{array}$ & 30 & 2.77 & 3.13 & $0.055^{\text {ns }}$ \\
$\begin{array}{l}\text { 4. Teacher ask questions } \\
\text { whenever necessary }\end{array}$ & 30 & 2.65 & 3.03 & $-0.317^{\text {ns }}$ \\
\hline $\begin{array}{l}\text { 5. Giving equal } \\
\text { opportunities to all } \\
\text { students to answer } \\
\text { questions }\end{array}$ & 30 & 3.03 & 2.83 & $0.094^{\text {ns }}$ \\
\hline $\begin{array}{l}\text { 6. Providing sufficient time } \\
\text { to answer }\end{array}$ & 30 & 2.90 & 2.87 & $-0.295^{\mathrm{ns}}$ \\
\hline
\end{tabular}

Note. $\mathrm{N}=$ Sample Size,${ }^{\mathrm{ns}}=$ non-significant

In practice, teachers hardly encouraged students to ask questions in the class $(M=2.20)$. Students were not given chance for raising their questions by the most of the teachers.
Teachers didn't ask open questions to the students $(\mathrm{M}=2.23)$, actually, only a few open questions were asked to the students in few classes. The mean value of teacher asking closed questions to the students (3.13) shows that teachers were good in this but improvement is possible. Teachers asked questions whenever appropriate $(M=3.03)$ but it can be improved. Questioning parts were almost dominated by the teachers. Teachers sometimes gave equal opportunities to all students to answer the question $(\mathrm{M}=2.83)$ and it need to be improved. Most of the time teachers asked questions in classroom pointing to a particular student. Very few teachers gave sufficient time to think the answers to students $(M=2.87)$. Most of the teachers did not give sufficient time to think the answers to the learners.

The Table 3 shows that teachers' perception about classroom questioning in the classroom has no significant relation with their practice as the $\mathrm{p}$ value is greater than 0.05. Although teachers' perception and practice of statement no. 1, 4 and 6 have weak negative correlation, all are statistically nonsignificant.

\subsubsection{Classroom assessment practice}

Table 4 presents that teachers strongly agreed to assess students through problem solving $(\mathrm{M}=3.30)$, practical work, and class test $(\mathrm{M}=3.26)$; use self and peer assessment $(\mathrm{M}=3.40)$ technique to assess students. They also expressed their agreement with the idea that students should be assessed both orally $(\mathrm{M}=2.87)$ and written work $(\mathrm{M}=3.00)$; through individual $(\mathrm{M}=2.93)$ and group work $(\mathrm{M}=3.13)$ and also asses students lower and higher order learning $(\mathrm{M}=3.03$ both).

Table 4: Teachers' Perception and Practices about classroom assessment practice

\begin{tabular}{|c|c|c|c|c|}
\hline \multirow{2}{*}{ Statements } & \multirow[t]{2}{*}{$\mathrm{N}$} & \multicolumn{3}{|c|}{\begin{tabular}{|l|l|l|} 
Perception & Practice & Correlation
\end{tabular}} \\
\hline & & Mean & Mean & Coefficient \\
\hline $\begin{array}{l}\text { 1. Using practical work, self- } \\
\text { assessment and class test }\end{array}$ & 30 & 3.26 & $\mathrm{a}$ & $\mathrm{a}$ \\
\hline $\begin{array}{l}\text { 2. Using peer assessment } \\
\text { technique }\end{array}$ & 30 & 3.40 & 1.60 & $-0.5^{*}$ \\
\hline $\begin{array}{l}\text { 3. Assessing through problem } \\
\text { solving }\end{array}$ & 30 & 3.30 & 1.40 & $-0.05^{\mathrm{ns}}$ \\
\hline 4. Assessing orally & 30 & 2.87 & 3.73 & $0.191^{\mathrm{ns}}$ \\
\hline 5. Assessing written work & 30 & 3.00 & 1.35 & $0^{\mathrm{ns}}$ \\
\hline $\begin{array}{l}\text { 6. Assessing through individual } \\
\text { work }\end{array}$ & 30 & 2.93 & 2.97 & $-0.312^{\mathrm{ns}}$ \\
\hline $\begin{array}{l}\text { 7. Assessing through group } \\
\text { work }\end{array}$ & 30 & 3.13 & 1.67 & $-0.139^{\mathrm{ns}}$ \\
\hline $\begin{array}{l}\text { 8. Assessing lower order } \\
\text { learning }\end{array}$ & 30 & 3.03 & 2.83 & $-0.263^{\mathrm{ns}}$ \\
\hline $\begin{array}{l}\text { 9. Assessing higher order } \\
\text { learning }\end{array}$ & 30 & 3.03 & 1.47 & $0.255^{\mathrm{ns}}$ \\
\hline
\end{tabular}

Note. $\mathrm{N}=$ sample size, ${ }^{*} \mathrm{p}<0.05,{ }^{\mathrm{ns}}=$ non-significant, ${ }^{\mathrm{a}}=$ in classroom observation, no teacher has practiced this activity so correlation cannot be computed because the variable became constant.

In practice teacher didn't conducted any practical work or used self-assessment technique to assess students. Teachers hardly used peer assessment technique $(\mathrm{M}=1.60)$ or problem solving/investigation work $(\mathrm{M}=1.40)$ to assess their students. Although teachers didn't conduct any class test to assess

\section{Volume 7 Issue 6, June 2018} www.ijsr.net 


\section{International Journal of Science and Research (IJSR) \\ ISSN (Online): 2319-7064}

Index Copernicus Value (2016): 79.57 | Impact Factor (2017): 7.296

students, they assured the researcher that they took class test according to the schedule of school authority and in their own way. Teachers did well in assessing students orally $(\mathrm{M}=3.73)$ but all the teachers used the most common technique i.e., oral questioning for assessing students learning in the classroom. Teachers did assessed students' knowledge through individual work $(\mathrm{M}=2.97)$ but they rarely assessed students through group $(\mathrm{M}=2.97)$ work and both need to be improved. Teachers did moderately well in assessing students' lower order learning $(\mathrm{M}=2.83)$ but improvement is required. Teachers were not assessing higher order learning $(\mathrm{M}=1.47)$ of students. In the classroom teachers asked almost all the questions from text books. Most of the questions were simply knowledge based especially objective questions. Very few teachers asked question which demanded higher order learning.

The Table 4 shows that teachers' perception about classroom assessment practice has no significant relationship with their practice as the $\mathrm{p}$ value is greater than 0.05. Although teachers' perception and practice of statement no. 3, 6, 7 and 8 have very weak negative correlation, they all are statistically non-significant. It means teachers who agreed to assess students individually, group work and their lower order learning; in practice they didn't perform these types of activities. Teachers' perception of assessing students through written work has no linear correlation with their practice but it's non-significant. Teachers strongly agreed to assess students through written work in science classes but in practice very few teachers had practiced it. Although teachers perceived to assess student through practical work, self-assessment technique and class test, in classroom observation no teacher was found to do any of the activity. So, correlation of these activities cannot be computed as one variable became constant. Teachers' perception about using peer assessment technique has moderate negative $(r=-0.5)$ correlation which is statistically significant. It means the teachers who strongly agreed to use peer assessment technique; in practice they are not doing it. In observation it was also found that only one or two teachers had used peer assessment technique in their class.

\subsubsection{Classroom feedback practice}

Table 5 presents that teachers strongly agreed to provide correct answer instead of punishing students in their failure $(M=3.40)$ and oral descriptive feedback $(M=3.30)$ to them. They also showed their agreement in providing oral positive evaluative feedback $(\mathrm{M}=2.73)$ and also both written descriptive $(\mathrm{M}=3.33)$ and evaluative $(\mathrm{M}=3.03)$ feedback to the students. Teachers disagreed to provide oral negative evaluative $(M=1.83)$ feedback to the students.

Table 5: Teachers' Perception and Practices about classroom feedback practice

\begin{tabular}{|l|c|c|c|c|}
\hline \multicolumn{1}{|c|}{ Statements } & $\mathrm{N}$ & $\begin{array}{c}\text { Perception } \\
\text { Mean }\end{array}$ & $\begin{array}{c}\text { Practice } \\
\text { Mean }\end{array}$ & $\begin{array}{c}\text { Correlation } \\
\text { Coefficient }\end{array}$ \\
\hline $\begin{array}{l}\text { 1. Teacher provided } \\
\text { correct answer instead } \\
\text { provoking/punishing } \\
\text { students in their failure. }\end{array}$ & 30 & 3.40 & 3.07 & $0.259^{\mathrm{ns}}$ \\
\hline $\begin{array}{l}\text { 2. Teacher provided oral } \\
\text { descriptive feedback. }\end{array}$ & 30 & 3.30 & 1.27 & $-0.031^{\mathrm{ns}}$ \\
\hline
\end{tabular}

\begin{tabular}{|l|l|c|c|c|}
\hline $\begin{array}{l}\text { 3. Teacher provided oral } \\
\text { positive evaluative } \\
\text { feedback. }\end{array}$ & 30 & 2.73 & 3.07 & $-0.206^{\mathrm{ns}}$ \\
\hline $\begin{array}{l}\text { 4. Teacher provided oral } \\
\text { negative evaluative } \\
\text { feedback. }\end{array}$ & 30 & 1.83 & 1.40 & $-0.586^{* *}$ \\
\hline $\begin{array}{l}\text { 5. Teacher provided } \\
\text { written descriptive } \\
\text { feedback. }\end{array}$ & 30 & 3.33 & 1 & ${ }^{\mathrm{a}}$ \\
\hline $\begin{array}{l}\text { 6. Teacher provided } \\
\text { written evaluative } \\
\text { feedback. }\end{array}$ & 30 & 3.03 & 1.20 & $-0.186^{\mathrm{ns}}$ \\
\hline
\end{tabular}

Note. $\mathrm{N}=$ sample size, ${ }^{*} \mathrm{p} \mathrm{p}<0.001,{ }^{\mathrm{ns}}=$ non-significant, ${ }^{\mathrm{a}}=$ in classroom observation, no teacher has practiced this activity so correlation cannot be computed because the variable became constant.

Most of the teachers provided correct answers when students failed $(M=3.07)$ and improvement is required. Sometimes, in some classroom activities punishment was given to the students for different causes in different ways. Most of the cases teachers did it when student failed to answers and/or made noise or disturbance in the class. Sometimes teachers had being using it as a technique to punish the students who made chaotic and interruption in the classroom and to warn other students so that they did not do it again. Teachers didn't provide oral $(\mathrm{M}=1.27)$ or written $(\mathrm{M}=1.0)$ descriptive feedback to the students. Usually feedback in the classroom was taken place in the form of oral evaluative feedback. Most of the teachers provided oral positive evaluative feedback $(M=3.07)$. Teachers were found to be praising students for their correct answers or any good works. "Good", "Very good" etc. were the most commonly uttered word for praising. Very few cases teachers used negative comments as a feedback $(\mathrm{M}=1.40)$ when students failed to give right answer of the questions. Teachers also didn't provide written evaluative ( $M=1.20)$ feedback.

The table 5 shows that teachers' perception about classroom feedback practice has no significant relationship with their practice as the $\mathrm{p}$ value is greater than 0.05. Although teachers' perception and practice of statement no. 2, 3 and 6 have very weak negative correlation, they all are statistically non-significant. . It means teachers who agreed to provide oral descriptive, positive evaluative feedback, in practice they didn't perform these types of activities. Although teachers perceived to provide written descriptive feedback, no teacher was found to practice it. So, correlation of these activities cannot be computed as one variable became constant. On the other hand, teachers' perception of providing oral negative feedback has moderate negative $(r=-$ .586) correlation with their practice which is statistically significant. It means the teachers who agreed to give oral negative feedback; in practice they are not doing it. In observation it was also found that teachers rarely entitled students bad or very bad based on their performance.

\section{Discussion of the Study}

The study revealed that most of the teachers perceive classroom assessment as summative assessment. It means teachers perceive classroom assessment as tests and they use 


\section{International Journal of Science and Research (IJSR) \\ ISSN (Online): 2319-7064}

Index Copernicus Value (2016): 79.57 | Impact Factor (2017): 7.296

tests to assign grade to the students' learning. Although tests are part of classroom assessment and could be used to assess some aspects of students' learning, they are incapable to answer all questions that a teacher would ask about his/her students. Susuwele-Banda (2005) argued that teachers that perceive classroom assessment as testing fail to understand the learning potentials and difficulties experienced by their students during the learning process. Yasmin (2012) also found that teachers are using classroom assessment to fulfill summative purpose. So, Teachers have lack of knowledge about classroom assessment.

The study reveals teachers opined that their purpose of classroom assessment is to provide guidance to the students learning but in practice they were different from their views. Usually Teachers assessed students to know how much they have learned. Teachers rarely use assessment information to modify their teaching although this is an important purpose (Ahmed, Islam \& Salahuddin, 2015). It is found that teachers thought classroom assessment as oral question and answer. In practice teachers also used oral questioning to assess students in science classroom. Similarly, researchers found that teachers mainly used oral question and answer to assess their students in classroom (Ahsan, 2009; Rahman \& Ahmed, 2010). Teachers mostly used oral questioning followed by written tasks, individual works and conversations (Ahmed et al., 2015). But Frey and Schmitt (2010) found in a study that paper-pencil test remained the commonly used assessment formats that the teachers used. Similarly, Zhang and Burry-stock (2003) showed that teachers who taught language, arts, science and social science used written test more often than the teachers who taught mathematics.

Teachers perceive to use different techniques to assess students but in practice teachers didn't use different techniques such as group work, written tasks, practical work or investigation work to assess students. Teachers had very limited ways and methods of assessing their students (Rahman \& Ahmed, 2010). It is also found that the teachers were not concerned about using different strategies for assessment in the classroom and they did not try to link students' knowledge with their classroom instructions. Teachers need to use different strategies to monitor students learning. Teachers should be employed a variety of assessment strategies to capture varied learning. No single strategies can be useful to all their students at the same time for the same purpose. Some strategies like written tasks, home works, quizzes, group works, peer works, assignments, probing questions, observation, clinical interview and thinking aloud may help teachers to understand the learning processes of students (Rahman \& Ahmed, 2010; Ahmed et al., 2015). When teacher place meaningful assessment at the center of classroom teaching learning, they give insights into their own thinking and growth, and students gain new perspectives on their potential to learn (Susuwele-Banda, 2005).

Although teachers perceive to use self and peer assessment techniques in the classroom, in practice no teacher practiced self-assessment to assess students learning. The present study observed that very few teachers among the observed classes practiced peer assessment in classroom. Similarly, other researcher found that self and peer assessment practice was absent (Rahman \& Ahmed, 2010) or very rare in the classroom of Bangladesh (Yasmin, 2012). But selfassessment as well as peer assessment is essential to students learning (Black \&Wiliam, 1998a).

It is very important for both teachers and students to assess the students before presenting a new science topic in the class. It helps teacher to shape their teaching learning activity and students can prepare them for the upcoming science topic. Although teachers perceive to explore students prior knowledge and connect them with new knowledge in practice teachers were irregular in exploring students' prior knowledge and teachers hardly connect them with new knowledge. In this study, findings pointed out that teacher explored students' prior knowledge through oral question and answer. Similarly, researchers found that teachers mostly used oral questioning to assess students prior knowledge (Ahsan, 2009). But Ahmed et al. (2015) found that teachers tried to make a connection between students' prior knowledge and new knowledge. One of the most important tasks of a science teacher is to know the alternative conceptions of students regarding the subject matter (Hackling, 2004). The findings of this research also suggested teachers perceive to explore students misconception but in practice teachers didn't explore students' misconception about science. Teachers do not use diagnostic assessment to explore students' misconception or alternate conceptions (Ahmed et al., 2015). Diagnostic assessment identify students misconceptions/alternative framework about science topics. Therefore, diagnostic assessments are strong assessment tools that help teachers to plan their teaching learning that meets students' needs.

Teachers' perception toward asking open questions was more favorable than closed questions in the science class. But in practice most of the time teachers asked closed questions in the class. Open questions were limited in the classroom. It was also found from the existing study that teacher assessed their students by mostly closed questions in the classroom (Ahsan, 2009; Rahman \& Ahmed, 2010; Yasmin, 2012). But Ahmed et al. (2015) found that teachers were more focused to use open questions to evaluate students learning whereas close questions were hardly thrown in the class. Black and Wiliam (1998a) states that good questions are hard to generate so teachers should collaborate and draw-critically on outside sources to collect such questions. But this is totally absent in the practices of teachers' classroom assessment. It is found in a study that a balance and strategic use of classroom questioning prompts students to consider their response more thoughtfully listen to and evaluate the responses of others and evaluate their own understanding (Torrance, 2007).

This study explored that although teachers' have favorable perception to assess students both lower and higher order learning in science class, in practice teachers mainly assessed students' lower order learning through oral questioning. Very few teachers asked question which demanded higher order learning. Similarly, other researchers examined that student higher order learning was almost ignored or rarely

\section{Volume 7 Issue 6, June 2018}




\section{International Journal of Science and Research (IJSR) \\ ISSN (Online): 2319-7064}

Index Copernicus Value (2016): 79.57 | Impact Factor (2017): 7.296

focused by teachers through classroom questioning (Ahsan, 2009; Rahman \& Ahmed, 2010). This study shows that questions posed by teachers in classroom assessment directly and/or indirectly encourages students in rote learning or memorization because teachers asked all questions from textbooks or simply knowledge based especially objective questions. Here, there is a great chance for students to reply any questions through memorization (Ahmed, 2002) as well as students do not have opportunity to be engaged in selfthinking or applying their learned knowledge in a concrete and new situation, nor do they have opportunities to develop higher order learning skill (Crooks, 1988; Ahmed, 2002). Yasmin (2012) also found that most of the time teacher asked recall type questions to the students. All assessment devices were knowledge-based questions, with other cognitive sub-domains left unexplored by teachers (Babu, 2016). Ahmed (2002) argued that students study science but they do not develop investigation or experimenting ability. There is a need to formulate deep learning through the classroom assessment of students. The questions or tasks should have been designed is such a way so that students can use prior and factual knowledge in solving a problem or carrying out a process, but cannot apply directly on their ability to recall the information (Crooks, 1988).

Classroom questioning was almost dominated by the teachers. It was also found from the existing study that teacher dominates the classroom questioning fully (Ahmed et al., 2015). Teachers focused on directional questions towards the lessons rather than motivational questions to students. Motivational questions are helpful for the process for the process of students higher order learning. The main purpose of these types of question is not to measure learning but encourage students in learning (Ahsan, 2009). This study found that teachers perceive to encourage students asking questions in the classroom and also giving equal opportunity to all for answering questions. But in practice teachers didn't encouraged students to ask questions in the class. Sometimes, teachers gave equal opportunities to all students to answer the question but most of the time teachers asked questions in classroom pointing to a particular student. Similarly, existing study found that students rarely received any chance for raising the questions to the teachers in the classroom (Ahsan, 2009) and even students didn't ask any questions if they failed to understand lesson or teachers' instructions (Rahman \& Ahmed, 2010). Babu (2016) also found that teachers did not create scope for students to ask questions, and students asked minimum amount of questions in science classes. Every student should have the equal opportunity to reply the asked questions in classroom assessment. Rahman and Ahmed (2010) discovered that teachers favorite learners, high achievers and students sitting in front benches were typically asked questions by teachers and the number of these students was very poor. Most students were deprived from the benefits of classroom assessment.

Sufficient time allocation for answering is important for students to prepare the anticipated answers. However, teachers do not allow enough time so that students could think out and offered an answer (Black \& Wiliam, 1998a). The study revealed that although teachers perceive to provide students sufficient time to answer, in practice most of the teachers did not give sufficient time to think the answers to the students. Very few teachers gave sufficient time (more than 10 seconds) to think the answers to students. It was also found from the existing study that teachers did not allow enough time for replying every question (Rahman \& Ahmed, 2010). Therefore, students do not try to think for responding the asked question, even if someone knows that the answer, or another question will come after a few seconds, the students do not try (Black \&Wiliam, 1998a). This study also revealed that only a few students in a class answered teachers' questions. Most of the students kept them silent to avoid answering because they felt they would not able to provide answers as quickly as selected students could and as the teachers were expecting.

Feedback is one of the most important factors for the students understanding of any subject matter and sustainable learning (Crooks, 1988). Classroom feedback can be provided in many forms. According to Stiggins (1991) teachers mostly use some forms of feedback, such as, verbal communication, nonverbal communication, written comments, performance ratings and test score. The study found that teachers perceive providing both oral and written feedback in classroom but in practice they mainly provide oral feedback. Teachers ignored written form of feedback for science classes. In maximum classes teachers didn't provide any feedback. Similarly, several studies found that teachers provide feedback through mainly oral form (Ahmed et al., 2015). But Yasmin (2012) found that teachers provide both oral and written form of feedback. Most of the time written feedback includes making comments using 'good', 'very good', putting 'cross/tick mark' on the answers.

This study explored that teachers' perception was more favorable to provide descriptive feedback than evaluative feedback to the students but in practice teachers mainly provided evaluative feedback to students. Generally, teachers let students know whether their answer was 'right' or 'wrong'. Descriptive feedback was absolutely absent in the science classes. In the existing study it was found that teachers generally practice evaluative feedback in the classroom (Ahsan, 2009; Rahman \& Ahmed, 2010; Ahmed et al., 2015) and descriptive feedback was absent or rarely practiced in classrooms of Bangladesh (Ahsan, 2009; Yasmin, 2012). Yasmin also (2012) found that teachers have emphasized on grades and marks as practice of feedback. Right-wrong answer feedback focuses on product of students learning rather than learning process. Like grades and marks, right-wrong answer feedback switches students' concentration 'how good I am' (Sadler, 2013). Chappuis and Stiggins (2002) reported that teacher comment that focus on students work could increase students' motivation and desire to learn. Feedback should be about the particular qualities of students work, with advice what they can do to improve, and should avoid comparisons with others (Black \&Wiliam, 1998a).

Teachers' perceptions are very important as they are what drive teachers' instructions in their classroom practices. The way teachers think about, understand, and value instruction influences their classroom practices. Teachers' perceptions

\section{Volume 7 Issue 6, June 2018}




\section{International Journal of Science and Research (IJSR) \\ ISSN (Online): 2319-7064}

Index Copernicus Value (2016): 79.57 | Impact Factor (2017): 7.296

of classroom have influence on their classroom assessment practice (Mussawy, 2009). This study reveals that teacher perception has no significant relation with their practice of classroom assessment. From the above discussion it can be easily understand that most of the teachers perceive classroom assessment as an integral part of teaching and learning and also most important component of their daily science classes. But in their reality they didn't practiced classroom assessment as they perceived or believed to do. Similarly, Yasmin (2012) also found that most of the cases teachers' attitude towards classroom assessment does not correspond to their instructional practice at all. Nga (2009) also found that teachers' classroom practices did not always correspond to their beliefs. To some extent, their classroom practices were based on their cognition and theories. To other extent, their beliefs were not reflected. But Jane (2013) found that teachers' knowledge, values, and beliefs played a significant role in the way teachers assess their students. In addition, she also found that most teachers perceive the use of assessment for learning strategies as a time-consuming task and added responsibility to their teaching assignment. The present study shows that teachers perceive classroom assessment as summative assessment and so although teachers agreed to use classroom assessment for the formative purpose, they failed to do that. Teachers' explained some common problem like extra work load, large class size, short period of class time, lack of availability of teaching aids and unsupported by their school authorities etc. for not practicing the classroom assessment as they perceive. Some school authorities forced non-science background teachers to take secondary science classes. These teachers could not assess students' science learning effectively as they should do. In classroom most of the teachers mainly use lecture method to present their lesson and oral assessment to measure students learning. Students are passive in assessment and their only job is to follow teachers lecture. Students are inattentive in both teaching learning activity and classroom assessment as students are not interested in teachers teaching learning and/or classroom assessments strategies.

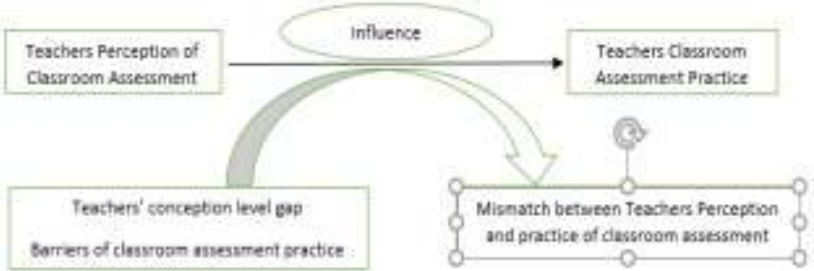

Figure 2: Relation between Teachers perception and practice of Classroom Assessment

Finally, it can be concluded that secondary school science teachers perception of classroom assessment didn't played any significant role to their current practice of classroom assessment in Bangladesh. Teachers' gap in the conception level and their mentioning barriers in classroom assessment may be the reason for not having any significant relationship between their classroom assessment perception and practice

\section{Implication of the study}

This study has contributed to the literature on classroom assessment of secondary science classes. The current study may contribute to a better understanding of the teachers' perception and practice of classroom assessment activities. This study attempts to establish to relationship between teachers perception and practice of classroom assessment in science. This connection is important as the training in educational assessment may prove to be necessary but not sufficient to make teacher practice what they perceive. This information can help educational assessment community to reconsider its training module to focus on teachers particular needs. This study also tried to explain teachers' perception of classroom assessment. It would be helpful for teachers to know what they need to do in assessing students in science classes. That will be ultimately beneficial to the students learning as well. This study reveals each and every task done by the teachers in the classroom and their effectiveness on students learning. This study explained how teachers' classroom assessment practice is not related to their perception. The teachers', who would like to change their assessment strategy according to their own perception and the students learning need, might find this study approachable to support their passion on the basis of applying classroom assessment activities for facilitating students science learning. The findings of this study shed light on the teachers' different needs of classroom assessment and through professional development necessary changes can be brought. Moreover, to bring a change in science curriculum and policy making, this study can be a point of reference. This study shows that although teachers are aware of different types of classroom assessment, they don't practice them effectively in the science classes. For the better learning of the students teachers should be efficient about different strategies of classroom assessment. The study pointed out that sometimes school authorities' forces non science background teachers to take science classes at secondary level. So, this study will help if school authorities and policy makers want to make any changes in this type's malpractice by administration of secondary schools of Bangladesh.

\section{Conclusion}

Teachers' perception of classroom assessment is favorable which means teacher should practice their assessment as they perceive it. But in numerous cases they are not practicing classroom assessment properly or as they perceive it to do. Teachers' perception of classroom assessment has no relation with their current practice of classroom assessment. Teachers perceive classroom assessment as summative assessment which may be a vital reason for teachers' inconsistency of assessment perception and practice. This is a very common scenario in our country that teachers try very little to guide student learning through classroom assessment. They mainly aimed to assess students' knowledge or memorization power in the classroom. The situation in all over the world is changing. But it is regret that no change yet has been seen in the secondary level classrooms of our country. Teachers may apply different assessment techniques like self-assessment, peer assessment in the classroom according to the needs of students learning. They must be facilitative to the students learning progress rather than students result.

\section{Volume 7 Issue 6, June 2018}




\section{International Journal of Science and Research (IJSR) \\ ISSN (Online): 2319-7064}

Index Copernicus Value (2016): 79.57 | Impact Factor (2017): 7.296

\section{References}

[1] Ahmed, S. S. (2002). The Effects of Public Examination on the Process of Students' Learning. Unpublished masters' thesis, Institute of Education and Research, University of Dhaka, Bangladesh.

[2] Ahmed, S. S., Islam, M. S., \& Salahuddin, M. (2015). Classroom Assessment Practices in Urban Secondary Science Classes in Bangladesh. NAEM Journal, 10(19), 32-42.

[3] Ahsan, S. (2009). Classroom Assessment Culture in Secondary Schools of Dhaka City. Teacher's World, Vol. 33-34, 231-244.

[4] Babu, R. (2016). Teaching Science in Bangladesh: Expectation versus Reality. Journal of Education and Learning, 10(3), 244-254.

[5] Begum, H. A., \& Ahmed, S. S. (2007). Assessment Tool Used in Secondary Schools: Do They Encourage Higher Order Learning? NAEM Journal, 3(5), 7-24.

[6] Black, P., \& Wiliam, D. (1998a). Inside the black box: Raising standards through classroom assessment. Phi Delta Kappan, 80 (2), 139-149.

[7] Black, P. \& Wiliam, D. (1998b). Assessment and classroom learning. Assessment in Education: Principles, Policy \& Practice, 5(1), 7-74.

[8] Buyukkarci, K. (2014). Assessment Beliefs and Practices of Language Teachers in Primary Education. International Journal of Instruction, 7(1), 107-120.

[9] Chappuis, S., \& Stiggins, R. J. (2002). Classroom Assessment for Learning. Educational Leadership, 60(1), 40-43.

[10] Crooks, T. J. (1988). The Impact of Classroom Evaluation Practices on Students. Review of Educational Research, 58(4), 438-481.

[11] Fennema, E., \& Romberg, T.A. (1999). Mathematics classrooms that promote understanding. New Jersey: Lawrence Erlbaum Associates.

[12] Danielson, C. (2008). Assessment for learning: for teachers as well as students. In C. A. Dwyer (Ed.), The future of assessment: Shaping teaching and learning, New York: Taylor \& Francis, pp. 191-213.

[13]Frey, B. B., \& Schmitt, V. L. (2010). Teachers' classroom assessment practices. Middle Grades Research Journal, 5(3), 107-117.

[14] Grant, T. J. (1996). Preservice Teacher Planning: A Study of the Journey from Learner to Teacher in Mathematics and Social Studies. Paper presented at the Annual Meeting of the American Educational Research Association, New York. Retrieved November 25, 2016, from http://files.eric.ed.gov/fulltext/ED398202.pdf

[15] Gurski, L. F. (2008). Secondary School Teachers Assessment and Grading Practices in Inclusive Classrooms. Unpublished masters' thesis, University of Saskatchewan, Saskatoon, Canada. Retrieved July 29, 2017,

from http://citeseerx.ist.psu.edu/viewdoc/download?doi=10.1. $1.615 .9149 \&$ rep $=$ rep $1 \&$ type $=$ pdf

[16] Hackling, M. W. (2004). Assessment in Science. In G. Venville \& V. Dawson (Eds.), The art of Teaching Science (1st ed., pp. 126-144). National Library of Australia.
[17] Jane, S. M. (2013). A vision of improvement of learning: South African teachers' conceptions of classroom assessment. Perspectives in Education, 31(2), 14-21.

[18] Mussawy, S. A. J. (2009). Assessment Practices: Student's and Teachers' Perceptions of Classroom Assessment. University of Massachusetts, Amherst. Retrieved November 22, 2016, from http://scholarworks.umass.edu/cie_capstones/9/

[19] National Curriculum and Text book Board, National Secondary Education Curriculum (2012). Dhaka.

[20] Ndalichako, J. L. (2015). Secondary School Teachers' Perceptions of Assessment. International Journal of Information and Education Technology, 5(5), 326-330.

[21] Nga, N. T. T. (2009). Teachers Beliefs about Teaching Reading Strategies and their Classroom Practices: A Case Study of Viet Ba High School. Vietnam National University, Vietnam. Retrieved December 30, 2016 from http://www.asian-efl-journal.com/Thesis-NNga.pdf

[22] Nenty, H. J., Adedoyin, O. O., Odili, J. N., \& Major, T. E. (2007). Primary Teacher's Perceptions of Classroom Assessment Practices as Means of Providing Quality Primary/basic Education by Botswana and Nigeria. Educational Research and Review, 2 (4), 74-81.

[23] Rahman, M. M., \& Ahmed, S. S. (2010). Classroom Assessment and Student Learning: An Exploration of Secondary School Teacher Practices. NAEM Journal, 5(10), 32-44.

[24] Sadler, D. R. (2013). Opening up feedback: Teaching learners to see. In Merry, S., Price, M., Carless, D., \& Taras, M. (Eds.). Re-conceptualizing Feedback in Higher Education: developing dialogue with students, (Ch. 5, 54-63). London: Routledge.

[25] Stiggins, R. J. (1991). Relevant Classroom Assessment Training for Teachers. Educational Measurement: Issues and Practice, 10(1), 7-12.

[26] Stiggins, R. J. (2010). Conquering the formative assessment frontier. In J. H. McMillan (Ed.), Formative classroom assessment, (pp. 8-28). New York, NY: Teachers College, Columbia University.

[27] Stiggins, R. J., \& Chappuis, J. (2005). Using StudentInvolved Classroom Assessment to Close Achievement Gaps. Theory into Practice, 44(1), 11-18.

[28] Susuwele-Banda, W. J. (2005). Classroom Assessment in Malawi: Teachers' Perceptions and Practices in Mathematics. Unpublished doctoral dissertation, Virginia Polytechnic Institute, State University, Virginia. Retrieved November 22, 2016, from https://theses.lib.vt.edu/theses/available/etd-02212005131851/unrestricted/wjs b_dissertation_JAN2005.pdf

[29] Torrance, H. (2007). Assessment as learning? How the use of explicit learning objectives, assessment criteria and feedback in post secondary education and training can come to dominate learning. Assessment in Education, 14(3), 281-294.

[30] Wiliam, D., \& Thompson, M. (2008). Integrating assessment with learning: What will it take to make it work? In C. A. Dwyer (Ed.). The future of assessment: Shaping teaching and learning. (pp. 53-82). New York: Lawrence Erlbaum Associates. 
[31] Yasmin, N. (2012). Exploring Secondary School Teachers' Attitude towards Classroom Assessment and its Implications for Students' Learning. Unpublished masters' thesis, Institute of Education and Research, University of Dhaka, Bangladesh.

[32]Zhang, Z., \& Burry-Stock, J. A. (2003). Classroom Assessment Practices and Teachers' Self-Perceived Assessment Skills. Applied Measurement in Education, 16(4), 323-342.

\section{Author Profile}

Md. Mehadi Rahman holds M. Ed in Educational Evaluation and Research by Institute of Education and Research (IER), University of Dhaka, Bangladesh. He achieved CGPA 3.99 out of 4 (1st position) in B. Ed (Honors) in Science Education from IER, University of Dhaka. He is currently working as Executive, Product \& Course Development in Light of Hope Company. 